PENGLIBATAN KOMUNITI DALAM MELESTARIKAN SUNGAI MELALUI PROGRAM PENAMBAHBAIKAN STOCK UDANG GALAH: KAJIAN KES DI SUNGAI PETAGAS, SABAH

\author{
Marthelreda Choo \\ Universiti Malaysia Sabah, Malaysia \\ mei.lee26@ymail.com \\ Gaim Lunkapis \\ Universiti Malaysia Sabah, Malaysia \\ gaimlunkapis@ums.edu.my \\ Ann Anton \\ Universiti Malaysia Sabah, Malaysia \\ aanton@ums.edu.my
}

*Corresponding author mei.lee26@ymail.com 


\title{
PENGLIBATAN KOMUNITI DALAM MELESTARIKAN SUNGAI MELALUI PROGRAM PENAMBAHBAIKAN STOCK UDANG GALAH : KAJIAN KES DI SUNGAI PETAGAS, SABAH
}

\begin{abstract}
ABSTRAK
Kertas kerja ini meneliti tentang penglibatan komuniti dalam melestarikan sungai melalui Program Penambahbaikan Stok Udang Galah di Sungai Petagas. Masyarakat merupakan salah satu komponen penting dalam mencapai pembangunan lestari bersama dengan kerajaan dan badan bukan kerajaan berkongsi tanggungjawab, merancang, mengurus, melaksanakan dan memantau alam sekitar. Penglibatan komuniti merupakan elemen yang penting dalam menjayakan program yang dilaksanakan oleh Institusi Penyelidikan Marin Borneo, Universiti Malaysia Sabah untuk bertujuan memulihara sungai tersebut. Kaedah kuantitatif menggunakan soal selidik dilaksanakan dengan memilih penduduk yang tinggal berdekatan dengan sungai di mana projek dijalankan. Berdasarkan penemuan kajian, penglibatan komuniti setempat dalam Program Penambahbaikan Stok Udang Galah dapat mengurangkan pencemaran di kawasan tersebut. Dengan ini, program yang dilaksanakan berupaya melestarikan sungai dan secara tidak langsung dapat membekalkan air bersih kepada komuniti.
\end{abstract}

Katakunci: penglibatan komuniti, penambahbaikan stok udang galah, melestarikan sungai 


\section{PENGENALAN}

Masyarakat merupakan salah satu komponen penting dalam mencapai pembangunan lestari bersama dengan kerajaan dan badan bukan kerajaan berkongsi tanggungjawab, merancang, mengurus, melaksanakan dan memantau alam sekitar seperti yang dinyatakan dalam Prinsip 22 dalam Local Agenda 21 (LA21) Rio de Janeiro, 1992, menghendaki satu komuniti masyarakat iaitu rakyat dan pemerintah untuk bersama-sama memainkan peranan penting dalam pengurusan alam sekitar dan pembangunan (Hassan, 2012). Kerajaan hendaklah mengiktiraf dengan cara yang sesuai bagi membolehkan penglibatan berkesan pelbagai pihak dalam mencapai pembangunan mampan. Penglibatan masyarakat yang berhampiran dengan sungai seharusnya melibatkan diri dalam apa juga aktiviti seperrti kempen atau program yang berkaitan dengan memulihara dan memelihara sungai. Ini kerana, masyarakat yang tinggal disekitar kawasan sungai dapat mengetahui keadaan sungai disamping membersihkan kawasan perumahan mereka. Penyertaan masyarakat setempat dalam proses membuat keputusan sangat penting dalam menyumbang idea-idea baru, maklumat, analisis serta penyelesaian kepada masalah tetapi turut menyumbang kepada pengetahuan dan maklumat asas dalam menentukan sebarang keputusan atau tindakan yang akan diambil (Haliza,2007).Dalam penglibatan masyarakat dapat meramalkan dan mengelak daripada masalah-masalah yang mungkin wujud atau berlaku di kawasan sungai seperti pertindihan antara adat dan peraturan yang ditentukan oleh kerajaan.

Insitusi Penyelidikan Marin Borneo (IPMB) ,Universiti Malaysia Sabah melaksanakan Program penambahbaikan Stok Udang galah di kawasan sungai Petagas pada tahun 2012 untuk bertujuan melestarikan kawasan sungai yang tercemar Pencemaran ini berlaku akibat daripada kewujudan penempatan manusia dan penyediaan tempat pembuangan sampah yang tidak strategik menyebabkan mereka (komuniti) mengambil jalan mudah untuk membuang sisa domestik ke dalam sungai. Menurut Datuk Seri Panglima Yahya Hussin dalam Borneo Post Online (2012), terdapat pihak yang tidak bertanggungjawab yang membuang sampah dan sisa daripada bahan industri ke Sungai Petagas dan menjadikan sungai itu tercemar. Oleh itu, Pihak UMS mewujudkan satu inisiatif dimana satu program yang melibatkan komuniti setempat untuk memulihara sungai tersebut. Dengan melibatkan komuniti dalam program dapat bertukar maklumat menyelesaikan konflik dan meningkatkan komunikasi antara pihak-pihak yang terlibat (Sanoff,1999).

Program Penambahbaikan Stok Udang Galah dilaksanakan sepanjang dua tahun iaitu dari tahun 2012 hingga 2014. Program ini, telah banyak mengadakan pelbagai kempen kesedaran kepada komuniti setempat disamping itu melepaskan beberapa ribu bibit udang galah untuk mengalakkan komuniti membersihkan sungai. Namun begitu, kajian yang dijalankan oleh haslina \& Regina ( 2009), masyarakat yang melibatkan diri menerima program yang dijalankan tetapi komuniti tidak ada kuasa membuat sesuatu keputusan dan akhirnya menarik diri daripada program kerana tidak berminat untuk teruskan program atas sebab-sebab tertentu.

Justeru itu, objektif kajian ini melihat sejauhmana penglibatan komuniti dalam melaksanakan pembangunan lestari melalui Program Penambahbaikan stok Udang Galah dan pemuliharaan Sungai Petagas dan sejauhmana kejayaan program yang dilaksanakan oleh kerajaan dan pihak UMS dapat mengurangkan pencemaran yang berlaku di sekitar Sungai Petagas.

\section{KONSEP LESTARI}

Perkataan Inggeris 'sustain' sudah ada sejak abad ke-13M dan berasal daripada Latin "Sustinere" yang bermaksud tahan yang membawa pengertan hold up, support atau endure. Sustainable muncul dalam abad ke-16M dengan maksud bertanggungkan atau bearable. Sustainable dangan makna boleh tahan atau defensible muncul dalam pertengahan abad ke-18M dan seterusnya berubah makna kepada "boleh terus-menerus bertahan pada aras tertentu" dan seterusnya dalam tahun 1970-an muncul perkataan sustainability iaitu kebolehan terus menerus bertahan pada aras tertentu (Shaharir, 2012). Perkataan lestari ialah kata asli Bahasa jawa yang bermakna selama-lamanya, tetap, kekal dan abadi. Kelestarian bermakna kebolehan bertahan selamaa-lamanya. 
Konsep pembanguanan lestari atau mampan menurut Laporan Brundtland yang bertajuk Our Comman Future telah didefinisikan sebagai "development that meets the needs of the present generation without compromising the ability of the future generation to meet their own needs" yang membawa erti suatu pembangunan yang memenuhi keperluan generasi masa kini tanpa mengabaikan keperluan generasi akan datang. Menurut Agenda 21, konsep pembanguan lestari atau mampan mementingkan kesejahteraan rakyat yang bergantung kepada kemakmuran ekonomi dan pembentukan insan yang berhasrat untuk hidup harmoni secara bermasyarakatan serta penglibatan awam dalam proses perancangan dan pembanguanan (Abdul Halim Ahmad, 2013).

Pembangunan bandar lestari adalah suatu proses membuat keputusan bersama oleh pihak yang berkepentingan dalam merancang bandar seperti Pihak Berkuasa Tempatan (PBT), persatuan peniaga setempat, Badan Bukan Kerajaan dan pengguna, bagi memastikan bahawa aktiviti ekonomi, kebajikan penduduk (termasuk kesihatan) dan ekosistem sama-sama diberi pertimbangan tersepadu bagi memastikan generasi kini dan akan datang dapat memenuhi keperluannya secara berterusan (Fatimah Yusof, 2008).

Secara kesimpulanya, konsep kelestarian atau sustainability adalah kebolehan ketahan secara berterusan untuk memenuhi keperluan generasi akan datang. Pembangunan lestari membawa maksud berlainan yang mempunyai kepentingan yang berbeza-beza. Ini kerana konsep pembangunan lestari tidak hanya terhad kepada alam sekitar dan sumber-sumbernya, malahan merangkumi masyarakat, ekonomi dan pembangunan fizikal.

\section{KONSEP PENGLIBATAN KOMUNITI}

Definisi penglibatann komuniti adalah sebagai satu bentuk tindakan sukarela yang mana individu mengambil peluang dan memikul tanggungjawab kemasyarakatan (Tosun, 2000). Ia merupakan satu proses masyarakat bekerjasama dengan mereka yang berupaua memberikan bantuan dalam perancangan, pengurusan dan penilaian tindakan yang juga memberi kesan kepada keadaan dan pembangunan mereka (Kalsom kayat \& Nor Ashikin, 2009).penglibatan komuniti menandakan bahawa keperluan dan aspirasi komuniti tersebut tidak diabaikan dan hasilnya ialah ahli komuniti itu akan mendapat didikan dan seterusnya diperkasakan (Askew, 1989 dalam Tosun 2000).

\begin{tabular}{|l|l|}
\hline Jenis & Ciri-ciri \\
\hline Penglibatan manipulative & $\begin{array}{l}\text { Penduduk dijadikan boneka dan dikatakan memegang jawatan tetaoi sebenarnya } \\
\text { projek pembangunan didalangi pihak luar.tahap kawalan oleh penduduk sangat } \\
\text { sedikit.hal ini menyebabkan faedah pembangunan kepada penduduk tidak } \\
\text { menentu. }\end{array}$ \\
\hline Penglibatan pasif & $\begin{array}{l}\text { Penduduk melibatkan dii dalam projek pembanguanan setelah keputusan } \\
\text { mengenai pembangunan dibuat oleh pihak penggerak. Maklumbalas penduduk } \\
\text { tidak diminya kerana lebih menekankan pendapat professional dari luar. } \\
\text { Pembangunan masih bukan di bawah kawalan penduduk }\end{array}$ \\
\hline $\begin{array}{l}\text { Penglibatan melalui } \\
\text { perundingan }\end{array}$ & $\begin{array}{l}\text { Agen luar merujuk kepada penduduk tempatan dengan meminta pendapat mereka } \\
\text { mengenai projek yang dibentuk oleh pakar dari luar, masih kurang kawalan dari } \\
\text { penduduk tempatan terhadap proses pelaksanan, perkongsian maklumat hanyalah } \\
\text { sehala, professional tidak perlu menerima pendapat penduduk. }\end{array}$ \\
\hline $\begin{array}{l}\text { Penglibatan } \\
\text { bermotivasikan pulangan } \\
\text { material yang diperlukan } \\
\text { oleh penduduk }\end{array}$ & $\begin{array}{l}\text { Penduduk melibatkan diri dengan menawarkan sumber seperti tenaga buruh bagi } \\
\text { mendapaatkan makanan, wang dan insentif kebendaan yang lain, penglibatan } \\
\text { bukan kerana mahu belajar mengenai kemahiran dan teknologi yang boleh } \\
\text { membantu meningkatkan taraf hidup setelah penglibatan selesai. }\end{array}$ \\
\hline Penglibatan berperanan & $\begin{array}{l}\text { Penglibatan penduduk dilihat sebagai penting untuk mencapai objektif projek } \\
\text { kerana penglibatan dilihat sebagai dapat mengurangkan kos, penglibatan adalah } \\
\text { dua hala dan melibatkan perkongsian dalam membat keputusan tetapi } \\
\text { penglibatann hanya terjadi setelah keputusan dibuat oleh pihak. }\end{array}$ \\
\hline Penglibatan interaktif & $\begin{array}{l}\text { Penduduk terlibat dalam analisis projek, pembentukan pelan tindakan, } \\
\text { penglibatan dilihat sebagai satu hak, bukan hanya sebagai agen untuk mencapai }\end{array}$ \\
\hline
\end{tabular}




\begin{tabular}{|l|l|}
\hline & $\begin{array}{l}\text { matlamat projek, proses oenglibatan menekankan penggunaan kaedah-kaedah } \\
\text { silang displin yang memerlukan pelbagai perspektif serta menggunakan proses } \\
\text { pembelajaran berstruktur. Kumpulan perancangan mengawal keputusan } \\
\text { penduduk tempatan dan menentukan bagaimana sumber yang ada igunakan dan } \\
\text { dengan itu mereka mempunyai kepentingan dalam memastikan struktur dan } \\
\text { kaedah dipatuhi. }\end{array}$ \\
\hline $\begin{array}{l}\text { Penglibatan pergerakan } \\
\text { sendiri }\end{array}$ & $\begin{array}{l}\text { Penduduk sendiri mengambil inisiatif utntuk menggerakkan projek } \\
\text { pembangunan, mereka menjalin hubungan dengan insituasi luar untuk bantuan } \\
\text { teknikal dan khidmat nasihat tetapi mengawal penggunaan sumber, penglibatan } \\
\text { jenis ini memerlukan kerangka sokongan dari kerajaan dan badan bukan } \\
\text { kerajaan. }\end{array}$ \\
\hline
\end{tabular}

Jadual 1: Jenis dan Ciri-ciri Penglibatan Komuniti

Sumber: Mowforth dan Munt (1998), Kalsom Kayat dan Nor Ashikin (2006)

\section{LATAR BELAKANG PROGRAM PENAMBAHBAIKAN STOK UDANG GALAH DI SUNGAI PETAGAS}

Penambahbaikan stok dan perladangan laut atau sea raching merupakan teknik baru dalam pengurusan perikanan yang memerlukan kerjasama diantara institusi pengajian tinggi (Universiti Malaysia Sabah) dengan pihak kerajaan (Jabatan Perikanan \& Pejabat Daerah Putatan) serta komuniti setempat bagi mendapatkan hasil yang lebih baik. Objektif program ini adalah meningkatkan pengeluran sumber perikanan di samping meningkatkan sosioekonomi nelayan dan memulihara sungai. Program Penambahbaikan Stok Udang Galah ini memberikan manfaat dalam melestarikan sungai petagas dengan melepaskan bibit udang galah ke dalam Sungai Petagas. Oleh itu, kaedah baru menggunakan sains dan teknologi diperlukan bagi memenuhi sasaran tersebut. Di samping, pelepasan bibit udang galah yang dihasilkan dalam hatcheri (tempat pembiakan udang galah) juga meningkatkan populasi udang asli di kawasan sungai.Udang Galah (M. Rosenbergii) dipilih kerana mempunyai daya ketahanan yang agak tinggi terhadap keadaan air yang keruh seperti yang terdapat di beberapa bahagian sungai Petagas. Program Penambahbaikan Stok Udang Galah melaksanakan beberapa fasa pelepasan bibit disamping membuat kempen kesedaran pentingnya sungai kepada komuniti setempat. Kempen yang dijalankan adalah untuk mempromosikan program dan memupuk minda komuniti untuk melestarikan sungai yang tercemar. Terdapat beberapa aktiviti program yang telah dijalankan sepanjang 2012 hingga 2014 seperti yang ditunjukkan dalam jadual 2.

\begin{tabular}{|l|l|l|}
\hline BIL & Tarikh & Aktiviti \\
\hline 1 & 23 April 2012 & Fasa 1: Pelepasan Bibit Udang Galah (4,000 bibit) \\
\hline 2 & 6 Disember 2012 & $\begin{array}{c}\text { Fasa 2: Pelepasan Bibit Udang Galah (6,000 bibit) } \\
: \text { kempen kesedaran di Kampung Petagas }\end{array}$ \\
\hline 3 & 22 September 2013 & $\begin{array}{c}\text { Fasa 3: Pelepasan bibit udang galah(10,000 bibit) } \\
: \text { Kempen Kesedaran di Kampung Petagas }\end{array}$ \\
\hline 4 & 12 Januari 2014 & Gotong Royong bersama komuniti setempat \\
\hline 5 & 18 Januari 2014 & $\begin{array}{l}\text {-Perasmiaan Sistem Tagal Sg Petagas } \\
\text {-Pelepasan Bibit Udang Galah (3,000 bibit) }\end{array}$ \\
\hline 6 & 19 Febuary 2014 & Lawatan komuniti ke Insitusi Penyelidikan Marin Borneo \\
\hline 7 & 11 July 2014 & Kempen kesedaran dan Ifar di SMK Putatan \\
\hline
\end{tabular}

Jadual 2: Pencapaian Program Penambahbaikan Stok Udang Galah

Sumber: Insitusi Penyelidikan Marin Borneo, UMS 2015

Program ini mempunyai 3 fasa dalam pelepasan benih udang galah di sungai petagas. Fasa pertama bagi insiatif penambahbaikan stok telah dijalankan pada 23 April 2012. Program ini dilancarkan oleh 
YB Datuk Seri Panglima Yahya Hussin, Menteri Pertanian \& Industri Makanan merangkap Timbalan Ketua Menteri Sabah. Kira-kira 4,000 benih udang galah telah dilepaskan di sungai. Fasa kedua dijalankan pada disember 2012, di mana sebanyak 6,000 benih udang galah telah disumbangkan kepada 10 buah kampung bagi tujuan pemuliharaan udang galah. Satu JawatanKuasa Pemantauan Sungai ditubuhkan bagi meninjau tahap kebersihan sungai di negeri ini khususnya Sungai Petagas di pinggiran Bandaraya Kota Kinabalu. Rumah Jeti di Kg. Muhibbah, Petagas akan dijadikan sebagai stesen penyelidikan sementara bagi penyelidikan dan pelajar UMS untuk menjalankan aktiviti pemantauan (Utusan Borneo, 2012).

Fasa ketiga dijalankan pada September 2013, sebanyak 10,000 benih udang galah telah dilepaskan lagi di sungai Petagas. Pada Januari 2014, sistem tagal telah dilaksanakan oleh Jabatan Perikanan dan IPMB, Ums telah melepaskan lagi 3,000 benih udang galah untuk menyokong Sistem Tagal tersebut. Menurut Datuk Seri Yahya Hussin, melalui sistem tagal penduduk akan bersama-sama menguatkuasakan peraturan tagal termasuk tidak membenarkan tangkapan ikan dalam tempoh tertentu serta memastikan sumber perikanan sungai tidak diancam sebarang bentuk pencemaran (Daily Express, 2014). Kempen-kempen kesedaran yang dianjurkan oleh Program Penambahbaikan udang galah ini adalah untuk memberikan kesedaran kepada komuniti bahawa sungai petagas tercemar dan mengalakkan mereka memulihara sungai tersebut.

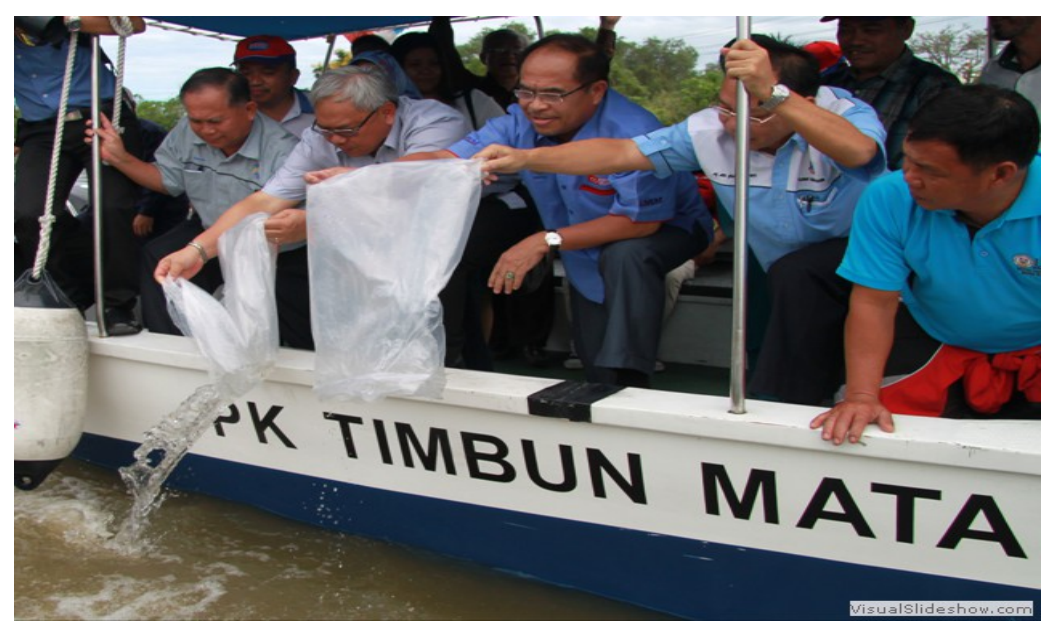

Rajah 1: Pelepasan Bibit Udang Galah Di Sungai Petagas

Sumber: The Borneo Post, 2012

\section{PENCEMARAN SUNGAI DI KAWAASAN SUNGAI PETAGAS}

Pencemaran adalah bahan-bahan asing yang menjejaskan kesihatan atau merosakkan kehidupan di bumi. Menurut Siti Khatijah (2009), menyatakan pencemaran adalah apa-apa perubahan langsung atau tidak langsung kepada sifat-sifat fizikal, haba, kimia, biologi atau radioaktif pada mana-mana bahgian alam sekeliling dengan melepaskan, mengeluarkan atau meletakkan bahan buangan hingga menjejaskan apa-apa kegunaan berfaedah, menyebabkan suatu keadaaan yang merbahaya atau mungkin merbahaya kepada kesihatan, keselamatan, kebajikan awam atau kepada binatang, burung, hidupan liar, ikan serta hidupan dalam air atau kepada tumbuh-tumbuhan dan menyebabkan suatu perlanggaran terhadap apa-apa syarat, had atau sekatan yang dikenakan ke atas sesuatu lessen yang dikeluarkan di bawah Akta Kualiti Alam Sekeliling, 1974. Pencemaran daripada punca tidak tetap terdiri daripada komponen pencemaran yang tidak dapat dikesan puncanya seperti air larian permukaan, sisaaktiviti pertanian, perladangan dan seumpamanya (Haliza, 2007). Pencemaran sungai di kawasan Sungai Petagas adalah disebabkan sikap dan tanggungjawab komuniti yang tidak memperdulikan penjagaan sungai di kawasan mereka. . Menurut Datuk Seri Yahya Hussin, keadaan 
sungai masih kotor terutama di tebing-tebing sungai yang masih terdapat sampah dan sisa buangan disebabkan terdapat pihak tertentu yang tidak bertanggungjawab membuang sampah dan sisa ke dalam sungai Petagas (Marryan Razan, 2012).

Selain itu, kekurangannya penyediaan kemudahan tong sampah dan sampah yang terbiar oleh majlis daerah Putatan juga menyumbang kepada pencemaran di kawasan sungai petagas. Hal ini menyebabkan komuniti setempat tidak mendapat membuang sampah di tempat yang betul dan mereka pun mengambil jalan yang mudah membuang sampah ke dalam sungai dan akhirnya sampah tersebut bertimbun di kawasan tebing sungai. Seorang pemilik rumah memberitahu bahawa sampah hampir sebulan majlis daerah putatan tidak mengambil sampah sarap yang bertimbun di kawasan mereka menyebabkan anjing liar mrmburukkan lagi keadaan kerana sisa-sisa sampah bertabur di jalanan (Daily Express, 2012)Oleh itu, usaha-usaha untuk memulihkan sungai petagas yang tercemar haruslah dilakukan dengan segera untuk kesejahteraan orang ramai.

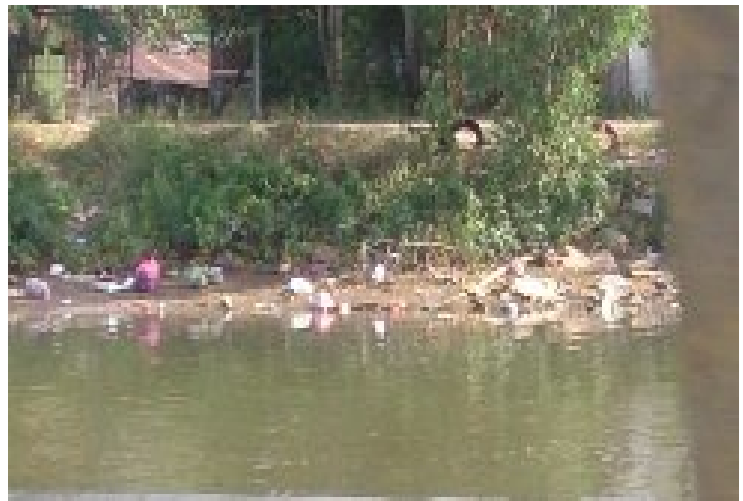

Rajah 2: Sampah Di Kawasan Sungai Petagas Sumber: penyelidik, 2012

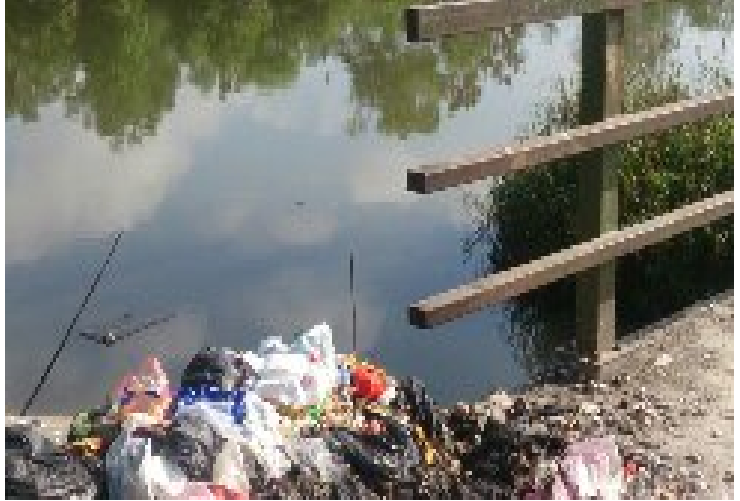

Rajah 3: Sampah Di Tebing Sungai Sumber: penyelidik, 2012

\section{LOKASI DAN METODOLOGI KAJIAN}

\section{Lokasi kajian}

Daerah Putatan adalah terletak di kawasan berhampiran dengan pantai seperti dalam Rajah 1. Daerah Putatan bersebelahan dengan Daerah Penampang. Pada asalnya, Putatan adalah sebahagian daripada daerah Penampang, namun, kawasan ini telah diisytiharkan sebagai daerah Putatan pada tahun 2011. Terdapat dua buah sungai utama di daerah ini iaitu Sungai Petagas dan Sungai Putatan yang merupakan antara sub-Lembangan yang terdapat dalam Lembangan Saliran Moyog yang lebih besar. 


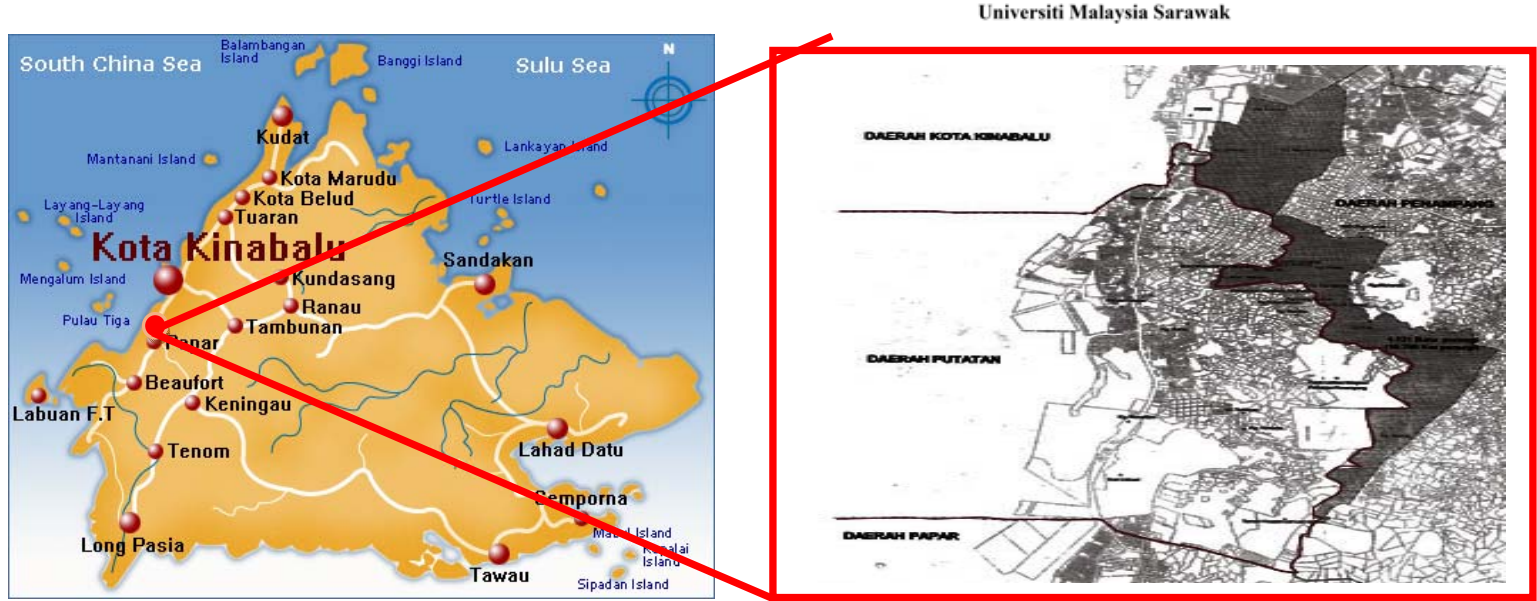

Rajah 4: Kawasan Pentadbiran Daerch Putatan

Sumber: Pejabat Daerah Putatan

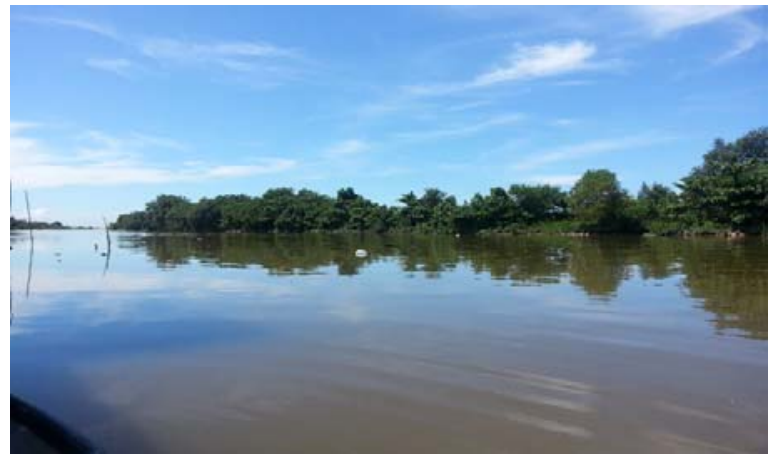

Rajah 5: Sungai Petagas

Sumber: Penyelidik, 2014

\section{HASIL KAJIAN}

Kaedah temu bual berstruktur melalui borang kaji selidik telah digunakan dalam proses pengumpulan maklumat. Kajian lapangan untuk mendapatkan data telah dilakukan pada awal bulan March 2014. Soal selidik ini hanya tertumpu di mana program ini dijalankan iaitu di kawasan sungai Petagas. Pengumpulan sampel telah dilakukan secara rawak sebanyak 50 orang responden, iaitu setiap isi rumah kampung berpeluang untuk ditemubual sama ada melibatkan diri dalam program atau tidak. Data dikumpulkan untuk mendapatkan maklumat tentang Demografi pengetahuan responden terhadap Program yang dijalankan, minat responden, perubahan yang berlaku dan kerjayaan Program tersebut, Pengkaji juga mendapatkan maklumat daripada ketua projek iaitu Prof. Datin Seri Panglima Dr. Hjh. Ann Anton dan melakukan turut serta dalam program Penambahbaikan Stok Udang Galah. 


\begin{tabular}{|c|c|c|c|}
\hline Demografi & & Frekuensi & Peratus $\%$ \\
\hline \multirow[t]{2}{*}{ Jantina } & Lelaki & 23 & 46.0 \\
\hline & Perempuan & 27 & 54.0 \\
\hline \multirow[t]{4}{*}{ Asal } & Sabah & 46 & 92 \\
\hline & Sarawak & 2 & 4 \\
\hline & Semenajung & 2 & 4 \\
\hline & Lain-Lain & 0 & 0 \\
\hline \multirow[t]{5}{*}{ Umur } & $<18$ tahun & 4 & 8.0 \\
\hline & 18-30 tahun & 21 & 42.0 \\
\hline & $31-40$ tahun & 15 & 30.0 \\
\hline & 41-50 tahun & 5 & 10.0 \\
\hline & 50 tahun $>$ & 5 & 10.0 \\
\hline \multirow[t]{5}{*}{ Tahap Pendidikan } & $\begin{array}{ll}\text { Tidak } & \text { mempunyai } \\
\text { pendidikan } & \end{array}$ & & 10.0 \\
\hline & PMR & 5 & 10.0 \\
\hline & SPM & 33 & 66.0 \\
\hline & STPM/DIPLOMA & 6 & 12.0 \\
\hline & IJAZAH/PHD & 1 & 2.0 \\
\hline \multirow[t]{5}{*}{ Pekerjaan } & Tidak bekerja & 15 & 30.0 \\
\hline & Bekerja sendiri & 12 & 24.0 \\
\hline & Sektor Kerajaan & 10 & 20.0 \\
\hline & Sektor Swasta & 5 & 10.0 \\
\hline & Masih bersekolah & 8 & 16.0 \\
\hline \multirow[t]{5}{*}{ Pendapatan Bulanan } & $<$ RM 500 & 22 & 44.0 \\
\hline & RM 500-1000 & 15 & 30.0 \\
\hline & RM 1001-2000 & 13 & 26.0 \\
\hline & RM 2001-3000 & 0 & 0 \\
\hline & RM 3000 > & 0 & 0 \\
\hline \multirow[t]{4}{*}{ Jenis Aktiviti } & Menangkap ikan & 11 & 22.0 \\
\hline & Berenang & 14 & 28.0 \\
\hline & Beriadah & 22 & 44.0 \\
\hline & Lain-lain & 3 & 6.0 \\
\hline
\end{tabular}

Jadual 3: Peratus dan Frekunsi Demografi Responden Komuniti Tempatan

Secara keseluruhannya Jadual 3 menunjukkan responden kajian kebanyakannya ialah perempuan (54\%) berumur antara 18 tahun hingga 30 tahun (42\%) dan berasal daripada Sabah (92\%), berpendidikan di tahap $\operatorname{SPM}(66 \%)$, tidak mempunyai bekerja $(30 \%)$ dan berpendapat kurang daripada RM500 sebulan (44\%) dan menjalankan aktiviti beriadah di Sungai Petagas.

\section{PENGETAHUAN RESPONDEN}

Pengetahuan komuniti tentang program penambahbaikan stok adalah penting untuk mengetahui samada mereka memahami objektif program dan juga tentang kewujudan program tersebut sebelum melibatkan diri mereka dalam program tersebut. Justeru itu, kajian ini telah menyoalkan beberapa soalan yang berkenaan dengan pengetahuan responden untuk tujuan tersebut. 


\begin{tabular}{|l|l|l|l|l|l|l|}
\hline Bil & Soalan yang ditujukan & \multicolumn{3}{|l|}{ Tahap kepuasaan (\%) } \\
\cline { 3 - 7 } & & STS & TS & TP & SS \\
\hline 1 & $\begin{array}{l}\text { Anda mengetahui tentang program aktiviti penternakan udang galah } \\
\text { yang dianjurkan oleh pihak UMS dan kerajaan }\end{array}$ & 0 & 0 & 12 & 54 & 34 \\
\hline 2 & $\begin{array}{l}\text { Anda pernah mendengar tentang program aktiviti udang galah di } \\
\text { Media Massa sebelum ini. }\end{array}$ & 14 & 16 & 48 & 20 & 0 \\
\hline 3 & Sedar tentang penternakan udang galah dapat melestarikan sungai & 0 & 4 & 28 & 64 & 4 \\
\hline
\end{tabular}

Jadual 4:Tahap kepuasan terhadap Pengetahuan Responden

Hasil daripada soal selidik yang dijalankan, kebanyakan responden sedar dan tahu (54\% setuju dan 34\% sangat Setuju) akan Program Penambahbaikan Stok Udang Galah yand dijalankan oleh pihak UMS dan kerjasama dengan Pejabat Daerah Putatan. Namun responden sama ada tidak pasti (48\%) dan tidak tahu (14\% sangat tidak setuju dan mereka pernah melihat iklan atau apa-apa yang mempromosikan program ini di media massa. Hampir majoriti responden sedar aktiviti yang dijalanakan ini dapat memulihara sungai yang tercemar (65\% setuju). Hasil daripada soal selidik yang dijalankan sebanyak 27 responden mengetahui tentang program yang dianjurkan oleh UMS dan pejabat daerah Putatan, Sabah dan 6 daripada 50 responden yang tidak pasti tentang program ini menunjukkan responden yang berkerjaya sibuk sehingga tidak mengetahui tentang program yang dilaksanakan di kawasan kampung mereka. Malah majoriti responden adalah surirumah yang lebih meluangkan masa di kawasan rumah dan mereka lebih cenderung mengetahui aktiviti yang berlaku di kawasan kampung.

\section{MINAT RESPONDEN}

Kajian ini juga mengkaji minat komuniti untuk melibatkan diri dalam program penambahbaikan stok udang galah.

\begin{tabular}{|l|l|l|l|l|l|l|}
\hline Bil & Soalan yang ditujukan & \multicolumn{3}{l|}{ Tahap Kepuasaan \% } \\
\cline { 3 - 6 } & & STS & TS & TP & S & SS \\
\hline 1 & $\begin{array}{l}\text { Anda tertarik untuk melakukan Program Penambahbaikan Stok Udang } \\
\text { Galah di sungai Petagas }\end{array}$ & 0 & 0 & 12 & 54 & 34 \\
\hline 2 & $\begin{array}{l}\text { Program Penambahbaikan Stok Udang Galah dapat menguntungkan } \\
\text { komuniti. }\end{array}$ & 14 & 16 & 48 & 20 & 0 \\
\hline 3 & $\begin{array}{l}\text { Dorongan keluarga menyebabkan anda tertarik dengan aktiviti udang } \\
\text { galah. }\end{array}$ & 0 & 4 & 28 & 64 & 4 \\
\hline
\end{tabular}

Jadual 5:Tahap kepuasan terhadap Minat Responden

Responden minat dalam Program Pelepasaan Udang Galah di sungai Petagas (54\% setuju dan 34\% sangat setuju). Ini mungkin adalah disebabkan dorongan keluarga (64\% setuju dan $4 \%$ sangat setuju) dalam menggalakan responden menjalankan aktiviti tersebut. Namun responden kebanyakan tidak pasti samada program ini dapat menguntungkan mereka (48\%). Hasil daripada soal selidik ini, kebanyakan responden bersetuju bahawa mereka berminat dalam menyertai Program Penambahbaikan Stok Udang Galah. Ini dapat dibuktikan melalui penglibatan 30 penduduk kampung dalam lawatan pentadbiran kampung Sungai Petagas anjuran Institusi Penyelidikan Marin Borneo (IPMB) UMS yang mengajar mereka penjagaan udang galah yang betul. Ini dapat disimpulkan penglibatan komuniti adalah Penglibatan bermotivasikan pulangan material kerana mengikut hasil kajian responden berminat dalam Program Penambahbaikan Stok Udang Galah di Sungai Petagas adalah disebabkan Program yang dianjurkan itu dapat menguntungkan mereka dari segi ekonomi serta dorongan keluarga dapat membantu mereka dalam aktiviti tersebut 
PERUBAHAN YANG BERLAKU DI SEKITAR SUNGAI PETAGAS

\begin{tabular}{|c|c|c|c|c|c|c|}
\hline \multirow[t]{2}{*}{ Bil } & \multirow[t]{2}{*}{ Soalan yang ditujukan } & \multicolumn{5}{|c|}{ Tahap Kepuasaan \% } \\
\hline & & STS & TS & TP & $\mathrm{S}$ & $\mathrm{SS}$ \\
\hline 1 & $\begin{array}{l}\text { Anda pernah melihat penduduk kampung menjalankan Program } \\
\text { Penambahbaikan Stok Udang Galah }\end{array}$ & 8 & 2 & 68 & 18 & 4 \\
\hline 2 & Komuniti semakin aktif dalam program aktiviti penternakan & 2 & 6 & 22 & 68 & 2 \\
\hline 3 & Terdapat aktiviti gotong-royong membersihkan sungai diadakan & 0 & 6 & 16 & 74 & 4 \\
\hline 4 & Terdapat perubahan sikap komuniti untuk membersihkan sungai & 0 & 2 & 36 & 60 & 2 \\
\hline 5 & Kerajaan aktif dalam pemantauan dan pengurusan sungai Petagas & 2 & 2 & 32 & 62 & 2 \\
\hline
\end{tabular}

Jadual 6: Tahap kepuasan terhadap Perubahan yang berlaku di Sekitar Sungai Petagas

Hasil dapatan kajian saya, responden tidak pasti (68\%) samada penduduk menjalankan program pelepasan udang di sungai tersebut sebelum ini tetapi responden bersetuju ( $68 \%$ setuju dan $2 \%$ sangat setuju) bahawa komuniti setempat adalah semakin aktif. Responden bersetuju (60\% setuju dan $2 \%$ sangat setuj) juga terdapat perubahan sikap komuniti untuk membersihkan sungai kerana terdapatnya aktiviti gotong royong diadakan di kampung tersebut. Responden juga bersetuju bahawa kerajaan aktif memantau dan mengurus sungai Petagas (62\% setuju dan $2 \%$ sangat setuju). Kajian mendapati hampir majoriti responden bersetuju bahawa terdapat perubahan ketara yang berlaku di kawasan sungai selepas Program Penambahbaikan Stok Udang Galah dilaksanakan iaitu kerajaan semakin aktif dalam pemantauan dan mengurus sungai dengan mengadakan Sistem Tagal yang baru dilancarkan. Ini menunujukkan kerajaan telah mula mengambil langkah agresif demi mengelakkan nelayan untuk menangkap ikan secara berlebihan di kawasan tersebut dan juga memelihara ekosisitem udang galah yang masih dalam peringkat juvenile. Dengan ini, spesies kehidupan akuatik dapat dipelihara di samping memulihara Sungai Petagas.

\section{PENCEMARAN SUNGAI BERKURANGAN}

\begin{tabular}{|l|l|l|l|l|l|l|}
\hline \multirow{2}{*}{ Bil } & Soalan yang ditujukan & \multicolumn{3}{l|}{ Tahap Kepuasaan \% } \\
\cline { 3 - 7 } & & STS & TS & TP & S & SS \\
\hline 1 & Pengurangan Pembuangan sampah di kawasan sungai petagas & 8 & 6 & 12 & 74 & 0 \\
\hline 2 & Aktiviti pembuangan sisa perindustrian telah berkurangan & 6 & 6 & 14 & 68 & 6 \\
\hline 3 & Aktiviti manusia telah berkurangan di kawasan sungai. & 0 & 0 & 22 & 68 & 10 \\
\hline
\end{tabular}

Jadual 7:Tahap kepuasan terhadap Pencemaran sungai semakin berkurangan

Responden bersetuju bahawa terdapat pengurangan pembuangan sampah (74\%), aktiviti pembuangan sisa perindustrian (68\% setuju dan $6 \%$ sangat setuju) dan aktiviti manusia (68\% setuju dan $6 \%$ sangat setuju) di kawasan sungai. Ini menunjukkan perubahan semakin ketara di kawasan sungai petagas kerana terdapatnya pengurangan pencemaran di kawasan tesebut. Secara keseluruhan kajian mendapati, terdapat pengurangan pencemaran sungai di kawasan tersebut. Aktiviti perindustrian dan aktiviti manusia juga semakin berkurangan atas pelaksaan undang-undang oleh kerajaan dan pihak yang terlibat. 


\section{KERJAYAAN PROGRAM PENAMBAHBAIKAN STOK UDANG GALAH}

\begin{tabular}{l|l|lllll}
\hline Bil & Soalan yang ditujukan & \multicolumn{4}{|l}{ Tahap Kepuasaan \% } \\
\cline { 3 - 6 } & & STS & TS & TP & S & SS \\
\hline 1 & $\begin{array}{l}\text { Program Penambahbaikan Stok Udang Galah Berjaya Melestarikan } \\
2\end{array}$ & 0 & 4 & 6 & 78 & 12 \\
Sungai Petagas & $\begin{array}{l}\text { Program Penambahbaikan Stok Udang Galah harus diteruskan bagi } \\
\text { memastikan sungai dalam keadaan bersih dan tidak tercemar. }\end{array}$ & 0 & 0 & 20 & 72 & 8 \\
\hline
\end{tabular}

Program Penambahbaikan Stok Udang Galah ini adalah Berjaya kerana responden bersetuju bahawa program ini melestarikan sungai Petagas( $78 \%$ setujuq dan $12 \%$ sangat setuju) dan ditreruskan bagi memastikan sungai dalam keadaan bersih dan tidak tercemar .(72\%setuju dan $8 \%$ sangat setuju). Berdasarkan kajian yang dijalankan didapati, kebanyakan responden bersetuju untuk meneruskan Program Penambahbaikan Stok Udang Galah kerana kejayaan program tersebut dalam melestraikan Sungai Petagas. Namun begitu, peruntukan untuk program ini hampir tamat namun terdapat segelitir pihak yang masih mengamalkan konsep Program Penambahbaikan Stok Udang Galah. Dalam pemerhatian penyelidik, terdapat dikalangan penduduk kampung yang telah melepaskan ketam dan anak ikan ke dalam sungai tersebut untuk memperbanyakan spesies dalam sungai itu. Selain itu, penduduk kampung di kawasan tersebut juga mengamalkan kitar semula untuk membersihkan kawasan perkampungan mereka.

\section{BENTUK PENGLIBATAN KOMUNITI}

\section{a) Lawatan ke Institusi Penyelidikan Marin Borneo (IPMB), Universiti Malaysia Sabah}

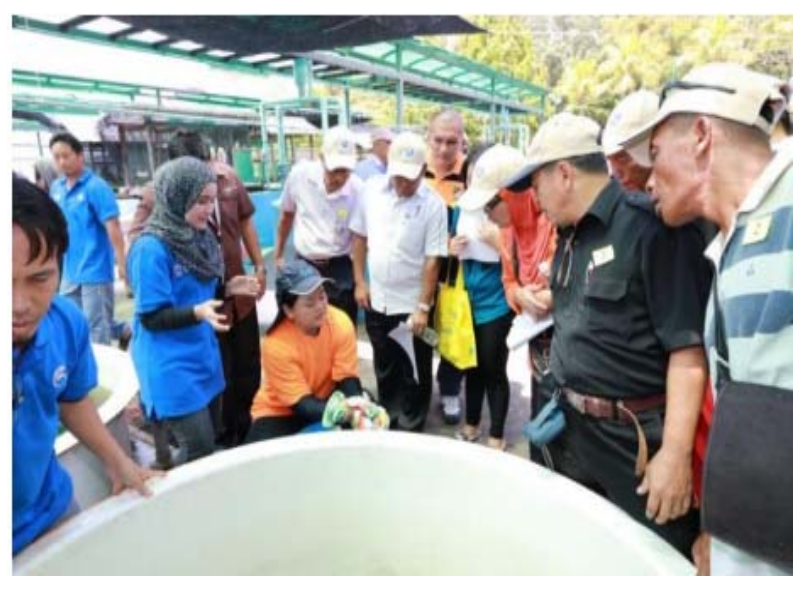

Rajah 6: IPMB menunjukkan cara-cara menternak gambar Udang galah Sumber : IPMB, 2015

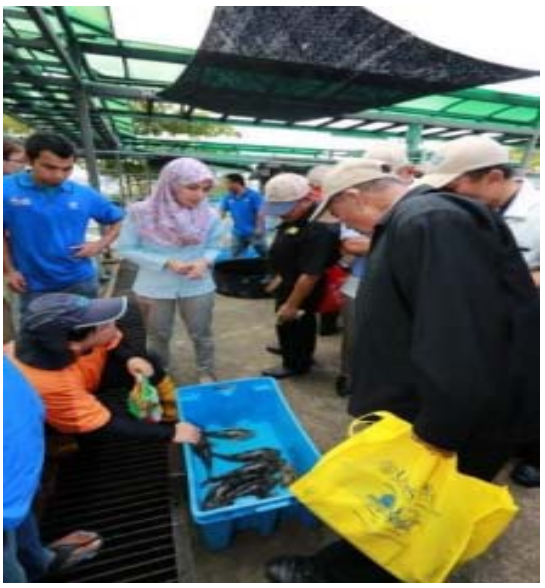

Rajah 7: IPMB berkongsi ilmu dengan komuniti Sumber :IPMB,2015

Pada 19 februari 2014, Insitusi penyelidikan Marin Borneo (IPMB),UMS telah menganjurkan satu lawatan pentadbiran kampung sungai petagas dan 30 orang penduduk secara sukarela yang melibatkan diri dalam lawatan tersebut. Lawatan ini adalah sebagai usaha IPMB berkongsi ilmu sambil memberikan peluang kepada komuniti untuk melihat lebih dekat teknik pengurusan serta penternakan udang dan ikan di UMS. Disamping itu, ahli komuniti diseru untuk bersama berganding bahu bagi memastikan projek yang dirancang berjalan dengan lancar.

b) Gotong Royong 


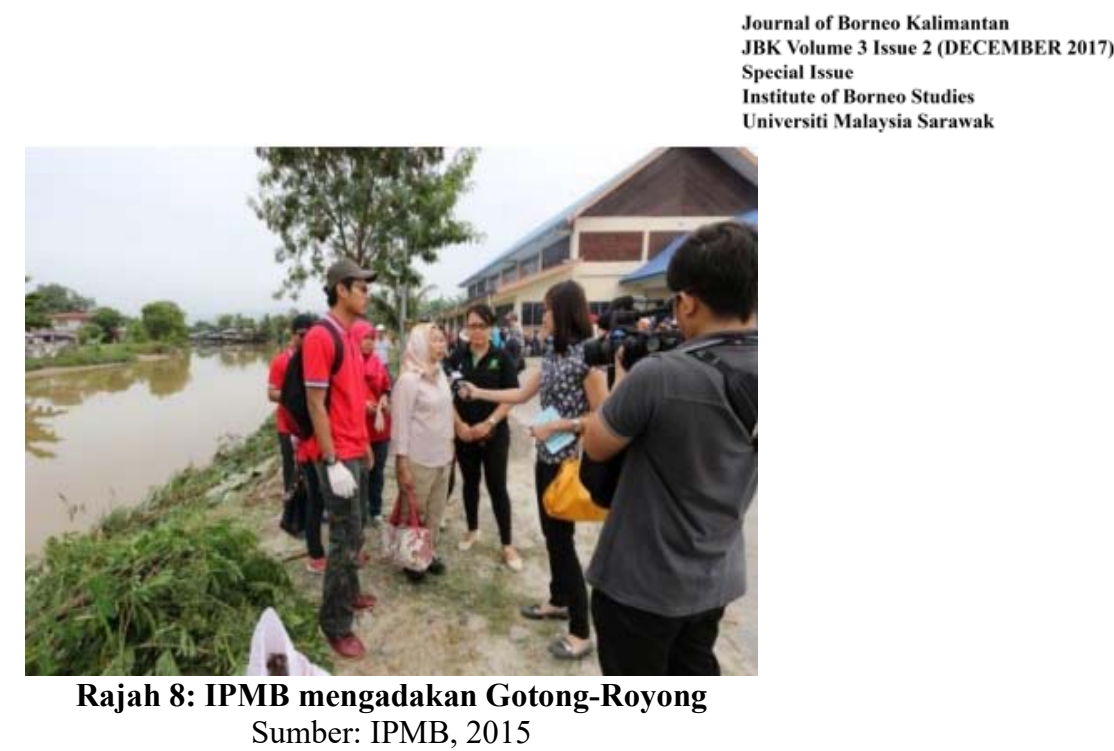

Pada 12 januari 2014, Insitusi Penyelidikan Marin Borneo, UMS telah mengadakan Gotong-Royong bersama dengan komuniti setempat untuk membersikan kawasan sekitar Sungai Petagas. Hampir majority penduduk kampung petagas melibatkan diri untuk membersihkan sampah sarap di sekitar sungai dan juga halaman rumah mereka.

\section{c) Sistem Tagal}

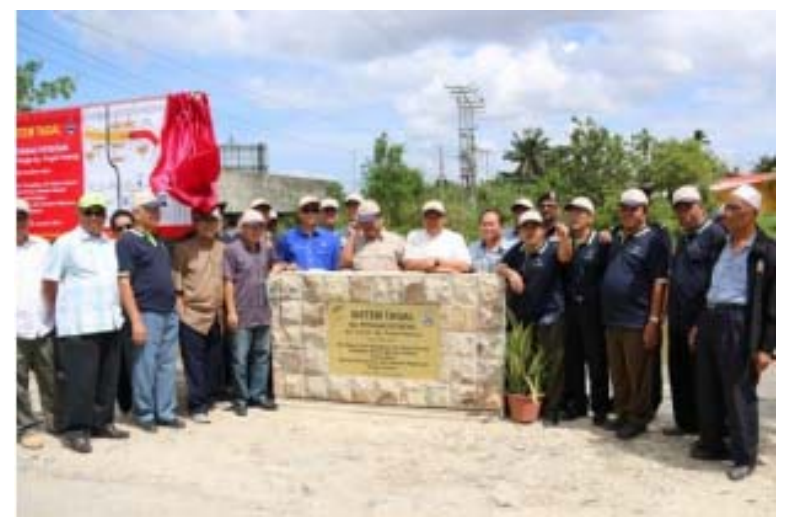

Rajah 9: Pelaksanaan Sistem Tagal

Sumber: IPMB, 2105

Pada 18 januari 2014, sistem Tagal dilaksanakan oleh Pejabat Daerah Putatan dan Insitusi Penyelidikan Marin Borneo.Sistem tagal merupakan satu pendekatan tradisional penduduk sabah dalam memulihara sumber perikanan sungai. Melalui sistem ini, tiada sesiapapun dibenarkan menangkap ikan di kawasan sungai yang ditagalkan. Sekiranya terdapat yang melanggar peraturan itu boleh dikenakan sogit (denda) oleh ketua kampung atau ketua daerah berdasarkan enakmen Perikanan Darat \& Akuakultur Sabah 2003 (New Sabah Time, 2014). Di samping itu, Timbalan Ketua Menteri Sabah Datuk Seri Yahya Hussin dan Menteri Pertanian dan Industri Makanan Sabah telah melepaskan 7 ribu bibit ikan dan udang yang terdiri daripada siakap, udang dalah dan ikan ketutu. Komuniti juga turut menghadiri majlis pelancaran di kawasan kampung mereka kerana IPMB telah menyediakan pelbagai aktiviti seperti pertandingan melukis, teka bibit udang galah dalam botol dan kempen kesedaran kepada mereka. 


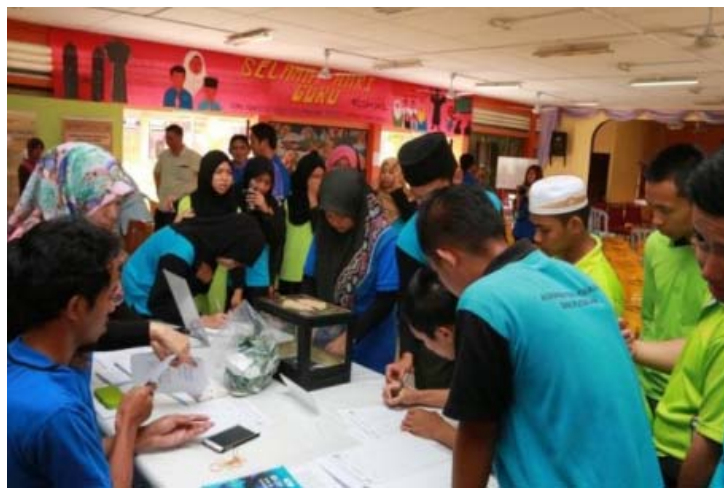

Rajah 10: Kempen Kesedaran Bersama Pelajar Smk Putatan

Sumber: IPMB, 2015

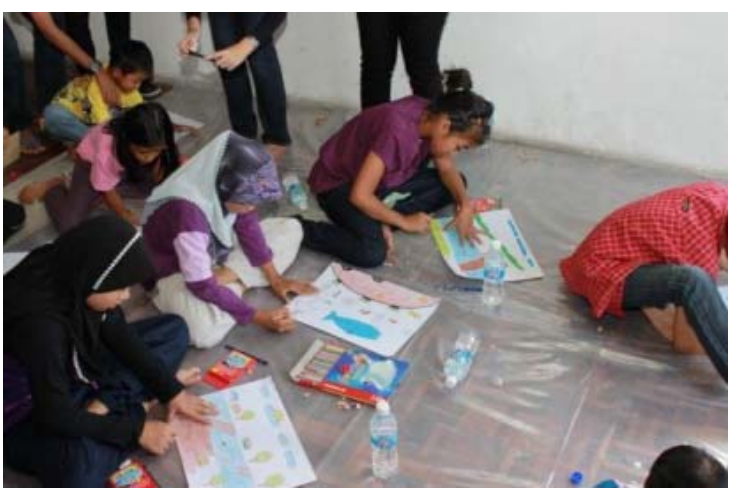

Rajah 11: Kempen Kesedaran Bersama Peduduk Kampung Sumber: IPMB, 2015

Salah satu aktiviti Program Penambahbaik Stok Udang Galah merupakan kempen kesedaran. Kempen yang dijalankan oleh pihak IPMB adalah pelbagai golongan termasuklah komuniti tempatan dan juga pelajar sekolah. Ini kerana program yang dijalankan adalah kepada golongan tidak mengira umur dan IPMB hendak memupukkan rasa cinta sungai dari akar umbi lagi. Dalam kempen kesedaran, terdapat pelbagai aktiviti yang disediakan untuk menarik perhatian kepada komuniti dan juga pelajar sekolah. Dengan cara ini, mereka tidak merasa bosan ketika berada di dalam dewan ceramah kesedaran kepentingan sungai.

\section{DAPATAN KAJIAN}

\section{a. Penglibatan Komuniti}

Secara keseluruhan, penglibatan komuniti dalam melestarikan sungai Petagas melalui Program Penambahbaikan Stok Udang galah mengikut Mowforth dan Munt (1998), adalah penglibatan berperanan iaitu penglibatan penduduk merupakan pemangkin untuk mencapai objektif projek kerana penglibatan dua hala dan melibatkan perkongsian dalam membuat keputusan. Objektif Program penambahbaikan udang galah ialah memulihara sungai dan menambah hasil perikanan di kawasan sungai Petagas. Objektif ini tidak dapat dicapai sekiranya kurang penglibatan penduduk kerana program yang dijalankan ini adalah untuk komuniti setempat dan perkongsian serta keputusan mereka juga adalah penting. Penglibatan yang efektif oleh semua pihak yang berkepentingan diperlukan untuk membangunkan satu pelan tindakan yang pratikal dengan meningkatkan kesedaran tentang etika alam sekitar di kalangan masyarakat setempat yang mana dapat mengawal pencemaran sungai dengan pembuangan sisia-sisa dari rumah (Annita et al, 2012)

Komuniti yang tinggal yang berhampiran dengan Sungai Petagas seharusnya menjaga kepentingan sungai tersebut tetapi masih terdapat komuniti mengamalkan budaya campak buang sampah, ini boleh dikaitkan dengan sikap masyarakat dan penyerahkan tanggungjawab sepenuhnya kepada kerajaan. Secara tidak langsung dapat menerangkan betapa rendahnya tahap penglibatan masyarakat daam usaha pemeliharaan sungai. Namun begitu terdapat juga segelintir masyarakat mengasingkan tin-tin dan kertas-kertas untuk dikitar semula serta aktiviti gotong- royong juga diadakan pada semasa ke semasa. Kerajaan juga harus menyediakan kemudahan tong sampah secukupnya di kawasan kedua kampung tersubut kerana kekurangnya penyediaan tong sampah akan menyebabkan penduduk kampung membuang sisa dosmatik mereka di sekitar sungai dan seterusnya menyediakan jadual pemantauan di sekitar sungai tersebut supaya sungai sentiasa dalam keadaan bersih. Majoriti responden adalah perempuan yang tidak bekerja dan mereka lebih banyak meluangkan masa berada di rumah dan di kawasan kampung. Oleh itu, mereka juga merupakan penyumbang utama kepada 
sampah sarap yang banyak dan kurangnya peranan kerajaan dalam penyediaan tong sampah menyebabkan golongan ini lebih cenderung membuang sampah sarap di kawasan tersebut. Selain itu, pentempatan juga merupakan punca menyebabkan pencemaran yang berlaku di Sungai Petagas. Kawasan perumahan yang berdekatan dengan lembangan sungai adalah lebih cenderung kepada pencemaran kerana sisa-sisa aktiviti manusia seperti sisa basuhan baju, sisa makanan dan lain-lain lagi secara langsung akan terus mengalir ke sungai menyebabkan sungai menjadi kotor dan mengeluarkan bau yang tidak menyenangkan.

\section{b. Minat Komuniti}

Kebanyakan responden dalam soal selidik memberikan padangan positif tentang Program Penambahbaikan Stok Udang Galah. Sebilangan mereka mengetahui tentang Program yang dianjurkan oleh IPMB UMS. Ini mungkin kerana kebanyakan responden yang tidak bekerja lebih cenderung berada di rumah lebih mengetahui keadaan kampung. Sehubungan dengan itu, mereka juga sering ke gerai minum untuk berkongsi pendapat dan bercerita kosong dengan rakan kampung kerena responden tidak pasti samada mereka pernah melihat iklan atau poster tentang Program tersebut di sekitar kampung. Komuniti juga sedar bahawa program ini dapat melestarikan sungai Petagas. Hal ini kerana majority responden adalah lepasan SPM yang lebih berpengetahuan daripada alam sekitar ketika di bangku sekolah lagi seperti kajian tempatan, ilmu alam dan subjek geografi. Komuniti adalah berminat untuk melibatkan diri dalam Program Penambahbaikan Stok Udang Galah kerana mereka berpendapat program ini dapat menguntungkan mereka dan juga adalah disebabkan dorongan keluarga untuk meningkatkan pendapatan mereka. Selain itu, komuniti merasakan Program Penambahbaikan Stok Udang Galah dapat meningkatkan pengetahuan mereka dalam memulihara dan memelihara sungai secara mapan. Dengan ini, mereka dapat bekerjasama dengan penganjur sebagai satu komuniti Petagas untuk membersihkan sungai.

\section{c. Kejayaan Program Penambahbaikan Stok Udang Galah}

Dalam 2 tahun Program Penambahbaikan Stok Udang Galah ini dijalankan, komuniti semakin aktif dalam melibatkan diri dalam membersihkan sungai. Ini terbukti dengan adanya, aktiviti gotongroyang yang diadakan di kedua kampung tersebut. Selepas program ini dilaksanakan, terdapat perubahan sikap di kalangan komuniti untuk memastikan sungai sentiasa bersih dan juga pihak berkuasa juga aktif dalam memantau dan mengurus sungai Petagas. Selain itu, tedapat pengurangan pembuangan sampah di sekitar kawasan sungai serta aktiviti pembuangan sisa dan aktiviti manusia juga telah berkurangan. Secara keseluruhannya, Program Penambahbaikan Stok Udang Galah telah Berjaya untuk melestarikan sungai Petagas seperti perbandingan di antara gambar $7 \& 8$ sebelum dan selepas Program Penambahbaikan Stok Udang Galah. komuniti juga menggalakkan program ini diteruskan pada masa hadapan untuk memastikan sungai sentiasa dalam keadaan bersih. 
Rajah 12: Sebelum Program Penambahbaikan Stok Udang Galah

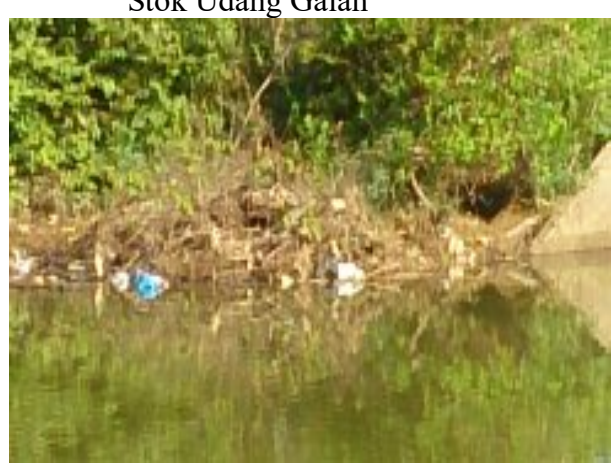

Sumber: penyelidik, 2012
Rajah 13: selepas Program Penambahbaikan Stok Udang Galah

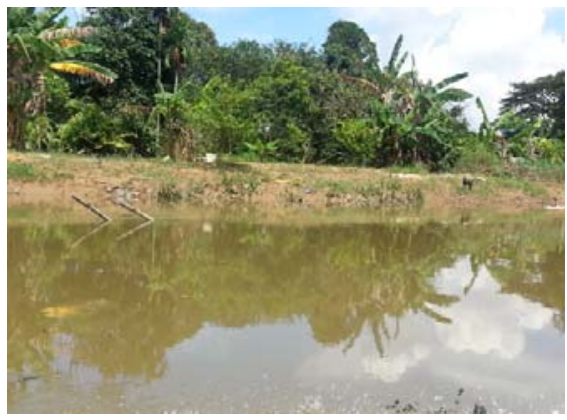

Sumber: penyelidik, 2015

\section{RUMUSAN DAN CADANGAN}

Program Penambahbaikan Stok Udang Galah adalah berjaya dilaksanakan untuk melestarikan sungai petagas dan memberi pendedahan kepada komuniti terhadap kepentingan menjaga alam sekitar di kawasan kampung mereka. Namun begitu, terdapat beberapa langkah lain untuk melestarikan Sungai Petagas iaitu dari segi perundangan dan juga bukan perundangan. Perundangan adalah berkaitan dengan akta-akta pencemaran sungai seperti Akta Kualiti Alam Sekitar 1974 yang merupakan perundangan utama berhubung dengan mencegah, menghapus, mengawal pencemaran dan membaiki alam sekeliling (Shamsuddin, 2003). Selain itu, terdapat juga perundangan lain yang berkaitan dengan pencemaran air iaitu Akta Jalan, Parit dan Bangunan 1974, Akta Kerajaan tempatan dan Akta Perikanan. Langkah bukan perundangan adalah seperti Pengurusan lembangan Saliran Bersepadu, ini adalah kerjasama antara angensi-agensi dalam pengurusan alam sekitar. Pendekatan pengurusan lembangan sungai bersepadu adalah satu proses penyelarasan dalam pemuliharaan, pengurusan dan pembangunan sumber air.

Dengan ini, sumber air sungai dapat diurus secara adil tanpa merosakkan keseimbangan ekosisitem. Merawat air yang tercemar juga boleh digunakan di Sungai Petagas dan kaedah ini juga pernah dilakukan oleh satu kumpulan ahli penyelidik dari Universiti Teknikal Malaysia Melaka (UTMM) yang menggunakan teknologi dalam menyenggaraan pencemaran air tasik dan sungai. Justeru itu, pendidikan alam sekitar juga harus dilaksnakan di bangku sekolah lagi. Sekolah adalah salah satu cara utama untuk menangani masalah-masalah yang berkaitan dengan alam sekitar. Pendidikan alam sekitar dapat membantu generasi masa hadapan untuk mengawal kehidupan mereka. Pendidikan alam sekitar bukan hanya di bangku sekolah sahaja tetapi boleh juga pendidikan dalam media cetak dan media elektronik terutama di televisyen yang boleh memaparkan kesan pencemaran sungai kepada masyrakat dan cara pengurusan sungai di rumah. 


\section{RUJUKAN}

Abdul Halim Ahmad Et Al. 2013. Kearah Pembangunan Mampan Setempat: Pelaksanaan Local Agenda 21 Oleh Pihak Berkuasa Tempatan Di Malaysia. Sosiohumanika: 6 (2). Hal 209-222.

Akta Kualiti Alam Sekeliling, 1974. Akta 127.

Annita Yong Et Al. 2012. Laporan Teknikal: Penambahbaikan Stok Perikanan Untuk Manfaat Masyarakat Setempat, Sabah. Sabah: Institusi Penyelidikan Marin Borneo, Universiti Malaysia Sabah.

Borneo Post. 2012. Over 4,000 Shrimps Released Into Petagas River To Improve Stocks. 24 April Hal 2.

Borneo Post Online. 2012 Jawatankuasa Pemantau Kebersihan Sungai Petagas Perlu Ditubuh. Diperolehi Daripada Http://Www.Theborneopost.Com/2012/12/06/Jawatankuasa-PemantauKebersihan-Sungai-Petagas-Perlu-Ditubuh/

Borneo Post. 2012. Putatan Needs Water Treatment And Sewerage Systems- Yahya. 24 April: Hal 2.

Borneo Post. 2012. Special Committee To Monitor River In Putatan. 7 Disember: Hal 7.

Borneo Post. 2012. Two More Projects To Release Aquatic Life Into Rivers. 24 April: Hal 2.

Daily Express. 2012. Need To Monitor River Quality. 7 Disember: Hal 2.

Daily Express. 2014. Sampah Tidak Dipungut Hampir Sebulan. Januari 15 Hal 8

Fatimah Yusof, Katiman Rostam \& Zikri Muhammad, 2008, Bandar Berdaya Saing Vis-À-Vis Pembangunan Bandar Lestari:Suatu Wacana Tentang Pembanguan Bandar Di Malaysia, University Teknologi Mara Shah Alam, Malaysia Journal Of Society And Space 4(85-98)

Haliza Abdul Rahman.2007. Suatu Tinjauan Terhdapa Isu Pencemaran Sungai Di Malaysia. Kelantan: Universiti Sains Malaysia.

Haslina Hashim \& Regina Garai Abdulllah, 2009, Penglibatan Komuniti Dalam Program Pembangunan Luar Bandar: Kajian Kes Di Pusat Pertumbuhan Desa Gedong, Sarawak, Akademika 77, Hal 41-67

Hassan Bin Yaakob. 2012. Penyertaan Awam:Kejayaan Dan Kegagalannya Dalam Perancangan Pembangunan. Jurnal Pengurusan Awam. Hal 67-84

Henry Sanoff, 1999. Community Participation Methods In Design And Planning. North Carolina State University

Kalsom Kayat \& Nor Ashikin, 2009, Penglibatan Ali Komuniti Dalam Program Pembangunan Komuniti:Satu Kajian Ke Atas Program Homestay Di Kedah, Akademika 67, hal 77-102

Kalsom Kayat \& Nor Ashikin, 2009, Faktor-Faktor Yang Mempengaruhi Penglibatan Ahli Komuniti Dalam Program Pembangunan Komuniti:Satu Kajian Ke Atas Program Homestay Di Kedah

Marryan Razan. 2012. Daily Express. Yahya Cadang Tubuh J-Kuasa Pemantau Sungai Di Sabah. 7 Disember: Hal 1.

Mowforth, M \& Munt, I (1998). Tourism And Sustainability: New Tourism In The Third World.London: Routledge 
New Sabah Times. 2014. 600 Lagi Sistem Tagal Akan Diwujudkan Di Sabah: Yahya. Januari 19 Hal 2

Shaharir Mohd Zain. 2012. Sains Keterlestarian Mengikut Perspektif Melayu Pra-Islam Dan Melayu Islam. Akademika 82(2). Hlm 101-108.

Shamsuddin Bin Suhor, 2003, Akta Kualiti Alam Sekeliling 1974 (Akta 127) Peranan Dan Keberkesanan Peraturan, Perintah Dan Kaedah-Kaedah Di Bawahnya. Jurnal Undang-Undang Dan Masyarakat 7, Hal 37-50.

Siti Khatijah Zakaria, 2009. Kajian Terhadap Sumber-Sumber Pencemaran Sungai Inanam Kota Kinabalu, Sabah. Ijazah Sarjana Muda. Universiti Malaysia Sabah.

Teuku Afrizal \& Abdul Rahman Embong. 2013. Komuniti Dan Pengurusan Persekitaran:Beberapa Pengalaman Malaysia,Bangladesh,Zambia Dan Vietnam, Universiti Kebangsaan Malaysia, Kajian Malaysia. Vol 31 No, Hal 65-86

Tosun, C (2000), Limit To Community Participation In The Tourism Development Process In Developing Countries, Tourism Management, 21,613-633

Utusan Borneo. 2012. Jawatankuasa Pemantau Sungai: Bagi Menjaga Dan Memastikan Kebersihan Sungai Sentiasa Berada Dalam Keadaan Baik. 7 Disember: Hal 1.

Utusan Online. 2010. Sediakan Tong Sampah Besar. Http:/Www.Utusan.Com.My/ Utusan/Info. Asp?Y $=2010 \& D t=1019 \&$ Pub $=$ Utusan_Malaysia $\&$ Sec $=J o h o r \& P g=W j \_01 . H t m$ Diakses Pada $30 / 4 / 2014$.

Utusan Borneo. 2012. Ipmb Harap Masyarakat Sokong. 24 April: 2.

Utusan Malaysia. 2009. Rawatan Air Tercemar Berteknologi Tinggi. 11 Jun. Hlm 12 \& 13. 